\title{
KNOWLEDGE MANAGEMENT DAN PENGARUHNYA DALAM PENGAMBILAN KEPUTUSAN PADA BADAN PEMBENTUKAN PERATURAN DAERAH DEWAN PERWAKILAN RAKYAT DAERAH KABUPATEN TAKALAR
}

\author{
Muh. Said ${ }^{1}$, Fatmawati², Lukman Hakim ${ }^{3}$ \\ 1,2,3) Universitas Muhammadiyah Makassar \\ e-mail: muhsaid2601@gmail.com
}

\begin{abstract}
Changes in the environment experienced by organizations require organizations to make adjustments to answer all future challenges. The strength that must be possessed by the organization is to realize the concrete concept that becomes a tool to make changes. One of them is knowledge management, because knowledge management is an organizational activity that manages knowledge as an asset, wherein various strategies there is the right distribution of knowledge to the right people in a fast time until they interact with each other from various knowledge and apply it in daily work for performance improvement. Knowledge Management integration in the decision-making process can be interpreted as a structured and systematic process in acquiring, distributing, and utilizing knowledge to support the decision-making process. The position of knowledge management in decision making is between two poles of knowledge, namely tacit knowledge on the one hand and the utilization of explicit knowledge in decision making on the other. Explicit knowledge emphasizes the implicit role of knowledge management in influencing actors involved in decision making. Research design using quantitative methods. The instruments used in this study were questionnaires. The results showed that the implementation of Knowledge management has a positive effect on decision making in the Regional Development Agency of Takalar regency.
\end{abstract}

Keywords: Knowledge Management, Decision-Making, Regional Representatives Council

\begin{abstract}
Abstrak
Perubahan lingkungan yang dialami organisasi mengharuskan organisasi melakukan penyesuaian diri organisasi untuk menjawab semua tantangan kedepan. Kekuatan yang harus dimiliki oleh organisasi yaitu mewujudkan konsep konkrit yang menjadi alat untuk melakukan perubahan. Salah satunya adalah pengelolaan knowledge management, karena pengelolaan knowledge management merupakan kegiatan organisasi yang mengelola pengetahuan sebagai asset, dimana dalam berbagai strategi ada penyaluran pengetahuan yang tepat kepada orang yang tepat dalam waktu yang cepat, hingga mereka saling berinteraksi dari berbagai pengetahuan dan mengaplikasikannya dalam pekerjaan sehari hari demi peningkatan kinerja. Integrasi knowledge management dalam proses pengambilan keputusan dapat dimaknai sebagai suatu proses yang terstruktur dan sistematis dalam mengakuisisi, mendistribusikan dan memanfaatkan pengetahuan untuk mendukung proses pengambilan keputusan. Posisi knowledge management dalam pengambilan keputusan berada di antara dua kutub knowledge, yaitu tacit knowledge di satu sisi dan pemanfaatan explicit knowledge dalam pengambilan keputusan di sisi yang lain. Explicit knowledge lebih menekankan peran implisit dari knowledge management dalam mempengaruhi aktor-aktor yang terlibat dalam pengambilan keputusan. Desain penelitian menggunakan metode kuantitatif. Instrumen yang digunakan dalam penelitian ini adalah kuesioner. Hasil penelitian menunjukkan bahwa implementasi Knowledge management berpengaruh positif terhadap pengambilan keputusan pada Badan Pembentukan Perda DPRD Kabupaten Takalar.
\end{abstract}

Kata Kunci: Knowledge Management, Pengambilan Keputusan, DPRD

\section{PENDAhuluan}

Era Revolusi Industri 4.0 pertama kali dipublikasikan pada tahun 2016 di Jerman. Era
Industri 4.0 menggunakan komputer internet of things, robotica, virtual reality dan kecerdasan buatan, sebagai dasarnya, kemajuan yang muncul di era industry 4.0 
yaitu komputer yang merupakan peralihan industry dengan penggunaan awal internet dimana Semua komputer tersambung ke jaringan bersama.

Di Era Revolusi Industry 4.0, dibutuhkan kemampuan teknologi informasi yaitu kemampuan jaringan internet berupa teknologi daring/on line, selain kemampuan teknologi jaringan dibutuhkan pula kemampuan berupa knowledge management dan learning organization, yang harus seiring dengan kemanpuan teknologi daring digital, robotika, karena di era teknologi tersebut mengalami suatu perubahan tatanan kehidupan yang cepat, dan berpengaruh terhadap perubahan karakteristik lingkungan kerja, dimana pada posisi Industri 4.0 selain menguasai Komputer dengan sisitim jaringan, sistim teknologi Daring digital yang pada akhirnya menggunakan sistim tersebut untuk keperluan pada pengambilan keputusan.

Perubahan lingkungan yang dialami organisasi mengharuskan organisasi melakukan penyesuaian diri, penyesuaian diri akan menjadi keharusan bagi organisasi untuk menjawab semua tantangan kedepan. Kekuatan yang harus dimiliki oleh organisasi yaitu mewujudkan konsep konkrit yang menjadi alat untuk melakukan perubahan. Salah satunya adalah pengelolaan knowledge management. Karena pengelolaan knowledge management merupakan kegiatan organisasi yang mengelolah pengetahuan sebagai asset, dimana dalam berbagai strategi ada penyaluran pengetahuan yang tepat kepada orang yang tepat dalam waktu yang cepat, hingga mereka saling berinteraksi dari berbagai pengetahuan dan mengaplikasikannya dalam pekerjaan sehari hari demi peningkatan kinerja pengambilan keputusan dilingkup organisasi.

Pada pengambilan keputusan, diperlukan knowledge management yang merupakan proses membentuk identitas pengetahuan, dimana knowledge management dapat mengatur, menyebarkan, dan mengirim informasi penting serta keahlian termasuk bagian dari ingatan organisasi yang terletak secara khas dalam lingkup organisasi yang tersusun rapih. Dengan demikin dapatlah dikatakan bahwa knowledge management adalah proses aktivitas manusia yang berhubungan dengan pengetahuan, dari berbagai jenis pengetahuan yang dikelola oleh suatu organisasi dengan pendekatan knowledge management seperti yang disampaikan oleh para ahli.

Davenport dan Prusak (2010), mendifinisikan bahawa "knowledge management difokuskan pada proses dan mekanisme untuk menemukan serta berbagi apa yang dikenal oleh organisasi atau stakeholder external. Kemampuan untuk berbagi pengalaman internal yang baik, dianggap penting untuk kinerja organisasi secara keseluruhan, juga mengemukakan bahwa memanfaatkan pengetahuan external sangat penting dalam mengarahkan inovasi kinerja organisasi secara umum." Selain knowledge management yang berperan untuk mempersiapkan sumber daya manusia, learning organization sangat dibutuhkan untuk pengembangan sumber daya manusia utamanya pada proses pengambilan keputusan.

\section{KAJIAN PUSTAKA}

Sebelum membahas pengertian knowledge management maka terlebih dahulu memahami pengertian knowledge, menurut Devenport dan Prusak (2010) knowledge atau pengetahuan didefinisikan sebagai berikut yaitu; knowledge merupakan campuran dari pengalaman, nilai, informasi kontekstual, dan intuisi mendasar yang memberikan suatu lingkungan dan kerangka untuk mengevaluasi, menyatukan pengalaman baru dengan informasi. Organisasi memerlukan knowledge, yang tersimpan sebagai dokumen repositori, dan rutinitas, praktek dan norma organisasi. Knowledge dibagi menjadi dua jenis yaitu explicit knowledge dan tacit knowledge, yang dapat dijelaskan sebagai berikut:

\section{Explicit Knowledge}

Adalah sesuatu yang dapat diekspresikan dengan kata-kata dan angka, serta dapat disampaikan dengan bentuk ilmiah. Knowledge jenis ini dapat segera diteruskan dari satu individu ke individu lainnya secara formal dan sistematis. Explicit knowledge juga dapat dijelaskan sebagai suatu proses, metode, mendapatkan pengetahuan yang bersifat formal, sistematis dan mudah untuk dipelajari dan ditransfer atau dibagikan ke orang lain dalam bentuk dokumentasi karena umumnya pengetahuan yang bersifat teori dimana memudahkan para ahli untuk membagi 
pengetahuannya kepada orang lain melalui buku, artikel dan jurnal tanpa harus datang langsung untuk mengajari orang tersebut.

\section{Tacit Knowledge}

Tacit knowledge bersifat sangat personal dan sulit dirumuskan sehingga sangat sulit untuk dikomunikasikan atau disampaikan kepada orang lain karena berbentuk perasaan pribadi, intuisi, bahasa tubuh, pengalaman fisik serta petunjuk praktis, tacitknowledge. Dibagi menjadi empat model konversi knowledge yaitu; model sosialisasi, externalization, combination, internalization yang biasa dikenal sebagai model SECI, yaitu:

a. Socialization merupakan proses berbagi knowledge, berbagi visi dan berbagi model mental antar anggota perusahaan untuk menciptakan knowledge yang baru. Sharing dan penciptaan tacit knowledge melalui interaksi dan pengalaman langsung. Tacit knowledge akandisampaikan melalui proses sosialisasi tim kerja (coaching).

b. Externalization merupakan konversi tacit knowledge menjadi explicit knowledge melalui proses dialog dan refleksi. Dengan kata lain, menerima dan membagikan knowledge yang dimiliki seorang individu kepada orang lain agar menjadi explicit. Konsep atau ide yang dimiliki dan dicoba dioperasionalkan, melalui proses learning by doing, untuk menghasilkan technical know-how yang baru. Hal ini akan dapat terjadi melalui proses simulasi praktikal.

c. Combination merupakan proses konversi dari explicit knowledge menjadi explicit knowledge yang baru diketahui. Pada proses combination explicit knowledge yang dimiliki para individu-individu dengan cara menyortir, menambahkan atau mengkombinasikan beberapa explicit knowledge, menjadi explicit knowledge yang baru. Hal ini akan dapat terjadi misalnya melalui proses on the job training dan praktek lapangan.

d. Internalization merupakan proses pembelajaran dan akuisisi knowledge yang dilakukan oleh semua anggota organisasi terhadap explicit knowledge yang disebarkan ke seluruh organisasi melalui pengalaman sendiri sehingga menjadi tacit knowledge bagi anggota organisasi. Pada akhirnya, knowledge yang bersifat explicit tersebut dapat dipelajari, dipahami dan dikembangkan sesuai dengan kemampuan masing-masing individu.

Pengelolaan suatu knowledge adalah suatu usaha untuk meningkatkan pengetahuan yang berguna di bidang organisasi, diantaranya membiasakan budaya berkomunikasi antar individu personal, memberikan kesempatan untuk belajar, dan menggalakkan saling berbagi pengetahuan. Dengan kata lain, pengelolaan knowledge merupakan seni yang menghasilkan value dari asset tidak berwujud (intangible assets) yang dimiliki. Berdasarkan dengan pengertian knowledge diatas maka dapatlah di tarik suatu pengertian langsung tentang knowledge management

Davenport danPrusak (2010) knowledge management, yaitu suatu rangkaian kegiatan yang digunakan oleh organisasi itu untuk mengidentifikasi, menciptakan, menjelaskan, dan mendistribusikan pengetahuan untuk digunakan kembali, diketahui, dan dipelajari di dalam organisasi. Kegiatan ini biasanya terkait dengan objektif organisasi dan ditujukan untuk mencapai suatu hasil tertentu seperti pengetahuan bersama, peningkatan kinerja, keunggulan kompetitif, atau tingkat inovasi yang lebih tinggi. Konsep knowledge management ini meliputi pengelolaan sumber daya manusia (SDM) dan teknologi informasi (TI) dalam tujuannya untuk mencapai organisasi yang semakin baik sehingga mampu memenangkan persaingan di era industry 4.0.

Perkembangan teknologi informasi memang memainkan peranan yang penting dalam konsep knowledge management. Hampir semua aktivitas kehidupan manusia akan diwarnai oleh penguasaan teknologi dan informasi. Jika berbicara mengenai knowledge management maka pengelolaannya menunjukkan makin cepat perubahan dalam segala bidang kehidupan, maka efek globalisasi serta perkembangan teknologi informasi akan sangat akseleratif.

Sehubungan dengan itu maka peranan knowledge management menjadi makin menonjol, karena hanya dengan knowledge management semua perubahan yang terjadi dapat disikapi dengan tepat. Ini berarti pendidikan memainkan peran penting dalam mempersiapkan SDM yang berkualitas dan kompetitif dan berkualitas dengan penguasaan 
pengetahuannya menjadi pilihan penting yang harus dilakukan dalam konteks tersebut.

\section{Knowledge Management Process}

Knowledge management process merupakan proses dari awal pengumpulan sampai dengan pemanfaatan dari knowledge tersebut pada organisasi, menurut para ahli telah mengemukakan tentang beberapa proses ataupun mekanisme knowledge management dimana proses tersebut terdiri dari knowledege discovery, knowledge capture, knowledge sharing, dan knowledge application. (BecerraFernandes 2004)

\section{a. Knowledge Discovery}

Tahapan awal dari kegiatan ini adalah processknowledge discovery (BecerraFernandes 2004) bahwa knowledge discovery merupakan proses pengubahan pengetahuan tacit menjadi explicitbaru dari data atau informasi pengetahuan yang sudah ada dan diketahui tentang bagaimana mendapatkan pengetahuan. Tahap selanjutnya Knowledge discovery adalah identifikasi infrastruktur yang ada, kita perlu melihat infrastruktur apa yang telah ada, misalnya perpustakaan, internet, media komunikasi internal, email, forum diskusi, digital library dan lain-lain. Infrastruktur ini merupakan explicit yang digunakan untuk membangun sistem mengelolah pengetahuan. Dari informasiinformasi tersebut akan diperoleh gambaran mengenai proses knowledge discovery pada knowledge management yang ada, dan infrastrukturnya apa yang bisa digunakan untuk membangun knowledge Discovery.

\section{b. Knowlege Capture}

Menurut Beccerra-Fernandes

Knowledge Capture merupakan proses pengambialan keputusan dengan menggunakan knowledge baik dengan explicit ataupun tacit yang berada pada diri individu atrau group. Dalam prosesnya knowledge captury terjadi sintesa atau pembentukan new knowledge dari knowledge-knowledge sebelumnya dalam konteks knowledge management yang menitik beratkan kepada pemunuhan kebutuhan dan sudut pandang pada pengambilan keputusan.

\section{c. Knowledge Sharing}

Menurut Beccerra-Fernandes (2004) knowledge sharing merupakan proses yang sudah dapat mengkomonikasikan explicit yang didapatkan dari tacit kepada individu lainnya ke orang lain dari ilmu tacit yang sudah di explicitkan, inti dari knowledge sharing adalah berbagi ide dari satu individu kepada individu lain proses ini biasanya tercipta dengan sendirinya dalam lingkup kerja group.

\section{d. Knowledge Application}

Menurut Beccerra-Fernandes (2004) Knowledge application adalah satu knowledgemanagement yang memungkinkan untuk mendukung pengambilan keputusan, mendukung perencanaan di berbagai fungsi organisasi, proses knowledge application terbagi atas dua hal yaitu direction dan routines, pada proses directions memperoses knowledge dengan tindakan tanpa proces transfer knowledge. Pada proses routines adalah proses yang melibatkan pemanfaatan dari knowledge management yang ada pada prosedur, aturan dan normayang ada.

\section{Strategi Knowledge Management pada Pengambilan Keputusan}

Integrasi knowledge management dan proses pengambilan keputusan dapat dimaknai sebagai suatu proses yang terstruktur dan sistematis dalam mengakuisisi, mendistribusikan dan memanfaatkan pengetahuan untuk mendukung proses pengambilan keputusan, posisi knowledge management dalam pengambilan keputusan berada di antara dua kutub knowledge, yaitu tacit knowledge di satu sisi dan pemanfaatan explicit knowledge dalam pengambilan keputusan di sisi yang lain. Lebih menekankan peran explicit knowledge dalam pengambilan keputusan dengan menekankan pemanfaatan peran explicit knowledge dalam proses pengambilan keputusan dalam model learning yang dibangunnya. Explicit knowledge lebih menekankan peran implisit dari knowledge management dalam mempengaruhi aktor-aktor yang terlibat dalam pengambilan keputusan.

Selain itu, proses pengambilan keputusan terutama yang bersifat strategis, biasanya tidak bersifat rasional, tetapi lebih didominasi pertarungan ide, intuisi, belief, wawasan, Sehingga fungsi knowledge management tidak cukup hanya sekedar mensuplai knowledge, 
tetapi juga harus menyediakan media dan perangkat untuk memfasilitasi diskusi untuk mendiseminasi konteks dan menyatukan persepsi bersama serta menyatukan informasi knowledge untuk membangun engagement yang sama dari orang-orang yang terlibat dalam proses pengambilan keputusan.

Rolland Nicolas (2004) menulis sebuah artikel hasil penelitian dalam Journal of Knowledge Management, yang berjudul: knowledge management impacts on decision making process. Dalam artikel ini Nicolas menemukan bahwa strategi knowledege management memiliki dampak terhadap proses pengambilan keputusan. Dampak knowledge management selain berupa pengaruh subtle terhadap orang yang terlibat dalam pengambilan keputusan, tetapi dapat dikatakan bersifat prosedural dimana knowledge management mempengaruhi pada setiap fase-fase pengambilan keputusan mulai dari fase intelligence, fase conception dan fase selection. Dibawa ini digambarkan fase pada pengambilan keputusan sebagai berikut;

\section{a. Fase Inteligence}

Sasaran fase inteligence adalah untuk memahami dan mengkonstruksi suatu isu. Pada fase explicit knowledge yang disuplai sistem knowledge management akan membantu proses pendefinisian masalah, sedangkan tacit knowledge dimobilisasi untuk memahami interaksi antara elemen-elemen yang membentuk situasi yang kompleks. Pada fase ini knowledge mengalir dari individu ke kelompok dan sebaliknya. Sehinggah proses pengambilan keputusan dapat berjalan lancar.

\section{b. Fase Conception}

Melalui fase conseption, para pengambil keputusan mengembangkan suatu situasi yang kompleks untuk menyediakan berbagai alternatif solusi. fase ini diwarnai oleh tindakan-tindakan, dimana para pengambilan keputusan memiliki pengetahuan bersama tanpa preferensi dari pengetahuan itu. Mereka merancang solusi-solusi baru atau mencari informasi dalam memory pengetahuan, tacit dan explisit dimobilisasi dengan interes dan frekwensi yang sama. Pada tahapan ini, berasal dari sifat ontologi atau kedalaman pengetahuan. Jika ontologi diatur sedemikian rupa, hubungan sebab-akibat akan diketahui. Tetapi jika ontologi sangat rumit, maka tingkat ketidakpastian akan terjadi menyebabkan lambatnya pengambilan keputusan.

\section{c. Fase Selection}

Fase seleksi mengevaluasi beberapa alternatif, dan memilih solusi yang akan ditindaklanjuti. Ini merupakan fasethe power ofuncertainty berada pada titik yang paling tinggi. Pilihan kadang terkait dengan explicit knowledge tetapi biasanya pengambil keputusan tidak dapat mengekspresikan alasan yang lebih mendalam dari pilihan mereka terkait dengan pilhan yang abstrak yang dapat memberikan kekuatan untuk memilh solusi.

Dengan demikian peran knowledge management dalam pengambilan keputusan tidak sederhana, karena proses pengambilan keputusan itu sendiri merupakan hal yang kompleks.

\section{METODE}

Desain Penelitian ini merupakan penelitian yang menggunakan metode kuantitatif. Instrumen yang digunakan dalam penelitian ini adalah kuesioner. Kuesioner adalah teknik pengumpulan data yang dilakukan dengan cara memberikan sekumpulan berbagai pertanyaan tertulis yang disusun secara sistematis dan diberikan kepada responden untuk dijawab.

Sampel penelitian ini adalah 42 Orang dengan teknik pengambilan Samplin jenuh Sumber data primer dan sumber data sekunder dengan teknik pengumpulan data dengan kuesioner /angket dan studi pustaka.

\section{HASIL DAN PEMBAHASAN}

Kosasih (2009) menemukan bukti empiris bahwa personal knowledge management berpengaruh secara langsung terhadap pengambilan keputusan. Karena knowledge management adalah suatu kegiatan strategis yang menambahkan nilai, pengelolaan knowledge management bertujuan untuk menciptakan nilai organisasi akan menghasilkan keunggulan kompetitif berkesinambungan serta dapat mengoptimalkan terhadap proses penciptaan, pengkomunikasian, dan pengaplikasian semua konwledge yang dibutuhkan dalam rangka pencapaian tujuan terhadap pengambilan keputusan. Knowledge management adalah kegiatan strategis yang menambahkan nilai 
sehingga dengan demikian, adahubungan erat antara knowledge management dengan rencana strategis organisasi yang menjamin bahwa variable knowledge management berkontribusi terhadap keunggulan strategis organisasi di DPRD. Hasil jawaban selengkapnya dapat dilihat pada tabel-tabel berikut yang mengambarkan distribusi frekuensi knowledge management yang didapatkan dari distribusi berdasarkan indikator-indikator dengan jawaban dari sangat Setuju, jawaban setuju, jawaban tidak setuju serta jawaban tidak setuju dari variabel yang diuraikan tersebut dapat dilihat pada tabel distribusi frekuensi tentang knowledge management sebagai berikut :

Tabel 1. Distribusi Frekuensi Tentang Knowledge Management

\begin{tabular}{|c|c|c|c|c|c|c|c|c|c|}
\hline \multirow{3}{*}{ No. } & \multirow{3}{*}{ Pertanyaan } & \multicolumn{8}{|c|}{ Tingkat Jawaban Responden } \\
\hline & & \multicolumn{2}{|c|}{1} & \multicolumn{2}{|c|}{2} & \multicolumn{2}{|c|}{3} & \multicolumn{2}{|c|}{4} \\
\hline & & $\mathrm{F}$ & $\%$ & $\mathrm{~F}$ & $\%$ & $\mathrm{~F}$ & $\%$ & $\mathrm{~F}$ & $\%$ \\
\hline 1. & $\begin{array}{l}\text { Kami memperoleh pengetahuan (knowlege) dari } \\
\text { pendidikan formal sehingga mampu } \\
\text { mengenalisa keputusan }\end{array}$ & 0 & 0 & 9 & 17,3 & 10 & 19,2 & 33 & 63,5 \\
\hline 2. & $\begin{array}{l}\text { Kami memperoleh pengetahuan (knowledge) } \\
\text { dari proses interaksi pengalaman kerja }\end{array}$ & 0 & 0 & 8 & 15,4 & 2 & 3,8 & 42 & 80,8 \\
\hline 3. & $\begin{array}{l}\text { kami memperoleh pengetahuan dari profesi } \\
\text { sebelumnya. }\end{array}$ & 0 & 0 & 5 & 9,6 & 3 & 5,8 & 44 & 84,6 \\
\hline 4. & $\begin{array}{l}\text { Kami memperoleh pengetahuan dari sharing } \\
\text { (knowledge) dari buku, majalah dan internet }\end{array}$ & 0 & 0 & 12 & 23,1 & 11 & 21,2 & 29 & 55,8 \\
\hline 5. & $\begin{array}{l}\text { Pengetahuan yang didapatkan dapat } \\
\text { diimplementasikan dengan baik. }\end{array}$ & 0 & 0 & 7 & 13,5 & 13 & 25,0 & 32 & 61,5 \\
\hline
\end{tabular}

Sumber: Data Primer Diolah 2020

Keterangan: Skor 1 = sangat tidak setuju, Skor 2 = tidak setuju, Skor 3 = setuju, Skor 4 = sangat setuju

Dari hasil tabel diatas dapat dilihat bahwa 5 indikator dengan nilai frekuensinya sangat setuju cukup tinggi dimana indikator 1 yaitu kami memperoleh pengetahuan (knowledge) dari pendidikan formal sehingga mampu menganalisa keputusan dengan nilais angat setuju $63,5 \%$. Untuk indikator 2 yaitu kami memperoleh pengetahuan (Knowledge) dari proses interaksi pengalaman kerja dengan nilai sangat setuju $80,8 \%$, pada indikator 3 kami memperoleh pengetahuan dari profesi sebelumnya dengan nilai sangat setuju $84,6 \%$ dan pada indikator 4 kami memperoleh pengetahuan dari sharing dari majalah dan internet dengan nilai sangat setuju 55,8\% dan pada indikator 5 yaitu pengetahuan yang didapatkan dapat di implementasikan dengan baik dengan nilai sangat setuju $61,5 \%$.

Berdasarkan uji $\mathrm{t}$ dengan menggunakan program analisa data SPSS versi 25 maka diketahui bahwa variabel bebas/independen (X1) berpengaruh positif signifikan terhadap pengambilan keputusan pada badan pembentukan perda DPRD Kabupaten Takalar (Y) pada uji t pada variabel knowledge management variabel $\left(\mathrm{X}_{1}\right)$ menghasilkan nilai t- hitung >t-tabel $(2.836>1.675)$ dan nilai sig.t $0,002<0,005$ maka dapat disimpulkan $\mathrm{H} 1$ diterima dan $\mathrm{H} 0$ ditolak artinya knowledge management (XI) berpengaruh positif dan signifikan terhadap pengambilan keputusan (Y) pada badan pembentukan perda DPRD Kabupaten Takalar. Dari empat tindikator tersebut dapat dimaknai bahwa penyebaran frekuensi setiap indikator pada variable knowledge management mempunyai pengaruh pada pengambilan keputusan atau secara keseluruhan distribusi frekuensi kuesioner pada variable knowledge management berpengaruh pada pengambilan keputusan, dan ada hubungan erat antara knowledge management dan rencana strategis organisasi yang menjamin bahwa variable knowledge management berkontribusi terhadap pengambilan keputusan pada Badan Bembentukan Perda DPRD Kabupaten Takalar. Oleh sebab itu maka pengelolaan knowledge management secara terus menerus perlu dikelola dimana karyawan bertukar pengetahuan dan pengalaman langsung dengan yang paling berpengetahuan. Sehingga akan didapatkan sebuah pengetahuan pengetahuan 
baru yang dapat menciptakan ide-ide baru yang memperkuat pengambilan keputusan.

\section{KESIMPULAN}

Berdasarkan hasil penelitian dan pembahasan, maka dapat ditarik kesimpulan bahwa Knowledge management berpengaruh pengaruh positif dan signifikan terhadap pengambilan keputusan pada badan pembentukan perda DPRD Kabupaten Takalar. Dengan nilai thitung 2,836 $>\mathrm{t}_{\text {tabel }} 1.675$ dengan nilai sig $0,002<0,005$.

\section{REFERENSI}

Amstrong, Michael. 2010. Manajemen Sumber Daya Manusia. Jakarta.PT Elexmedia Komputindo. Jakarta

Bawono, Anton. 2006. Multivariate Analysis dengan SPSS. Salatiga: STAIN Salatiga press.

Becerra-Fernandez, 2004. Organizational Knowledge Management: A Contingency Perspective. Journal of Management Information Systems.

Davenport, Prusak. 1998. Working Knowledge , How Organizations Manage What They Know. Harvard Business School Press, Boston.

Ghozali. (2011). Aplikasi Analisis Multivariete Dengan Program IBM SPSS. Semarang: Badan Penerbit Universitas Diponegoro.

Hadi, Sutrisno. 2001. Metodologi Research Jilid III. Yogyakarta: Andi Offset.

Harris, R. 1998. Introduction to Creative Thinking . [Online]. Tersedia: http://www.virtualsalt.com/crebook1.ht m [ 10 Oktoner 2014 ].

Jannis,I \& Mann, L. (1977) Decision Making: Psychological Analysis of Conflict, Choice and commitment. The Free Press: New York

Kim . 2000. Cloning and Expression of a Cysteine Proteinase Gene from Paragonimus westermani Adult Worms. J. of Parasitol.

O Brien James.2014. Sistem Informasi Manajemen Jakarta : Salemba Empat

Pella, D. A. \& Inayati, A. (2011). Manajemen Talenta: Mengembangkan SDM Untuk Mencapai Pertumbuhan dan Kinerja Prima. Jakarta: PT Gramedia Pustaka Utama 